\title{
Effect of Natural and Artificial Ascorbic Acid Supplementation on the Growth Performance and Packed Cell Volume of Broiler Chicks
}

\author{
Ufele Angela Nwogor, Okoye Chidiebere Bridget, Ebenebe Cordelia Ifeyinwa
}

Zoology Department, Nnamdi Azikiwe University, Awka, Nigeria

\section{Email address:}

ufeleangel@yahoo.com (U.A. Nwogor)

\section{To cite this article:}

Ufele Angela Nwogor, Okoye Chidiebere Bridget, Ebenebe Cordelia Ifeyinwa. Effect of Natural and Artificial Ascorbic Acid Supplementation on the Growth Performance and Packed Cell Volume of Broiler Chicks. American Journal of Life Sciences. Vol. 3, No. 3, 2015, pp. 158-161. doi: 10.11648/j.ajls.20150303.15

\begin{abstract}
This research studied the effect of natural and artificial ascorbic acid supplementation on the growth performance and packed cell volume of broiler chicks. The experimental animals used were sixty (60) broiler chicks of three weeks old. Five broiler chicks were randomly assigned to each cage and there were four cages representing four different treatments. Cage A served as control where only water was given to the broiler chicks as treatment 1 . Cage B contained chicks given $300 \mathrm{mg}$ natural ascorbic acid per liter of water as treatment 2 . Cage $\mathrm{C}$ contained chicks given a mixture of $150 \mathrm{mg}$ natural and $150 \mathrm{mg}$ artificial ascorbic acid per liter of water as treatment 3 while cage D contained chicks given $300 \mathrm{mg}$ artificial ascorbic acid per liter of water. The birds were given the respective treatments for five weeks and the experiment was replicated three times. At the end of the experiment it was observed that broilers fed with natural ascorbic acid had the highest weight gain $(1.22 \mathrm{~kg})$, followed by birds fed with natural and artificial ascorbic acid (1.09kg). Broilers fed with artificial ascorbic acid recorded a weight gain of $(0.89 \mathrm{~kg})$ while the control group has the least weight gain of $(0.79 \mathrm{~kg})$. Again broilers fed with natural and artificial ascorbic acid recorded the highest PCV gain $(21.23 \%)$, followed by broilers fed with artificial ascorbic acid (18.1\%). Broilers on the control diet recorded a PCV gain of (12.84\%) while broilers fed with natural ascorbic acid recorded the least PCV gain of (9.93\%). From the result of the experiment, it was observed that natural ascorbic acid enhanced growth of the broiler chicks while combination of both natural and artificial ascorbic acid boost the PCV of the broiler chicks.
\end{abstract}

Keywords: Broiler Chicks, Natural and Artificial Ascorbic Acid

\section{Introduction}

Malnutrition is the major problem in Nigeria, most of Nigerian diet has poor supply of animal protein. The recommended total protein intake for normal growth and development in man is $65.9 \mathrm{~g}$ per day, out of which approximately $34 \mathrm{~g}$ should be of animal origin (Aletor and Osungwu, 1991). However, only $7-10 \mathrm{~g}$ of animal protein is consumed per person, per day in Nigeria, (Ene, 1987). Brookes (2001) highlighted the importance of animal protein to human development. According to him, animal proteins are rich in essential amino acid especially lysine and methionine that are limiting in most plant proteins. They are also rich in trace mineral, vitamins and unidentified growth factors. The presence of certain animal protein particularly meat, egg and fish can improve the nutritional value of the entire diet, (Douglas, 2003). Poultry production especially broiler chicken remain one of the viable way of achieving sustainable and rapid production of high quality animal to meet the increasing demand of the Nigerian teeming population. However, high cost of energy and protein concentrates used in formulation of poultry feeds has remained a significant challenge to the poultry industry, (Apata and Ojo, 2000). At present, the high cost of inputs has become limiting factor to the growth of poultry industry, (Adejoro, 2000). A rapid growing broiler needs to be supplied with sufficient amount of protein and carbohydrates, along with the necessary vitamins, dietary minerals and an adequate supply of water in order to meet its requirements for maintenance and growth of all 
components of the bird, including feathers. Rapid increase in growth has been associated with improved feed conversion efficiency while ascorbic acid requirements as supplement of the diet have not changed substantially, (Gillespie et al., 2010).

Ascorbic acid belongs to the water soluble group of vitamins and it is a vitamin found mainly in fruits and vegetables. Because it is derived from glucose, many animals including birds are not able to produce it but they require it as a dietary micronutrient. Ibiyo et al., (2006) also have a detailed account of the importance of ascorbic acid stating that it improves immune function and growth. Research data indicate that supplementation with ascorbic acid should be considered as management alternative to prevent vitamin $\mathrm{C}$ deficiencies when poultry are stressed, (Quarles and Adrian, 1989). There are different methods to supplement ascorbic acid such as injection, dietary supplementation or water supplementation as found by Pardue et al., (1985). Gross, et al (1980) reported that exposure of birds to high environmental temperature causes an increase in the plasma corticosterone that subsequently depressed the activity of the lymphoid organs and total leucocytes count. The role of ascorbic acid by Schemling and Nockles (1978) was found to reduce the amount of corticosterone in the plasma with subsequent maintenance of the normal leucocytes count. It is vital for the body to receive an optimal amount of vitamin $\mathrm{C}$ because the production of collagen is linked directly to vitamin $\mathrm{C}$; therefore, if there is a lack of vitamin $\mathrm{C}$, there is an absence of collagen, and the body will literally fall. Due to these functions, vitamin $\mathrm{C}$ especially in combination with zinc is also important for the healing of wounds, (Escott-Stump, 2008).

Ascorbic acid is a naturally occurring organic compound with antioxidant properties. It is a white solid, but impure samples can appear yellowish. It dissolves well in water to give mildly acidic solutions. Ascorbic acid is one form of vitamin C. It was originally called L-hexuronic acid, but when it was found to have vitamin $\mathrm{C}$ activity in animals the suggestion was made to rename L-hexuronic acid to ascorbic acid, (Li, and Schellhorn, 2007). Vitamin C enhances the immune system. The immune system main operation is to protect the body from foreign substances or toxins. For the immune system to function correctly, vitamin $\mathrm{C}$ must be present. Vitamin $\mathrm{C}$ is extremely important in this function because it is involved with T-cells and white blood cells. The white blood cells function is basically to monitor various disease conditions. Because vitamin $\mathrm{C}$ boosts the white blood cell count, an individual who consumes high doses of vitamin $\mathrm{C}$ has a less likely chance of contracting disease, (Douglas et al., 2007). Although vitamin $\mathrm{C}$ can be synthesized by poultry, the synthesis is reduced or the requirements for vitamin $\mathrm{C}$ are increased during times of stress. During times of environmental, nutritional or pathological stress, the addition of ascorbic acid to the birds' feed or to their drinking water appears to alleviate many of the undesirable physical consequences of exposure (e.g., chronic adrenocortical activation, immunosuppression, weight loss and reduced egg production) to single or multiple concurrent stressful stimuli such as high environmental temperature, beak trimming, coccidiosis challenge and transportation (Pardue and Thaxton, 1986).

The PCV or haematocrit is measured by the proportion of volume of the blood occupied by red blood cells which is determined by centrifuging the blood at about 5000rpm for five minutes in a centrifuge and expressed as a percentage. Bull et al., (2001) defined Haematocrit as the compact volume occupied by red blood cells in a given volume of blood, expressed as a percentage.

\section{Materials and Methods}

\subsection{Procurement of Experimental Animal}

A total of 60 broiler chicks at four weeks old, already vaccinated for New castle and Gumboro were used for the experiment. The birds were randomly selected into four (4) treatment groups of five birds each. Each group was replicated three times. The birds were allowed to acclimatize in their new environment for one week before the commencement of the experiment.

\subsection{Experimental Treatments}

The broilers were given pelletized broiler finisher feed. The treatment they received was mixed with their water. Treatment 1 was used to feed broilers in cage A in which ordinary water was given to the birds without any inclusion. Treatment 2 was used to feed broilers in cage B which contained $300 \mathrm{~g}$ natural ascorbic acid per liter of water. Treatment 3 was used to feed broilers in cage $C$ which contained $150 \mathrm{mg}$ of natural ascorbic acid and $150 \mathrm{mg}$ of artificial ascorbic acid. Treatment 4 was used to feed broilers in cage D which contained $300 \mathrm{mg}$ of artificial ascorbic acid. The treatments were served as drinks in the broilers drinkers. Natural orange juice was used as source of natural ascorbic acid while pharmaceutical ascorbic acid was used as artificial ascorbic acid.

\subsection{Data Analysis}

The weight of the birds was taken weekly using a sensitive weighing balance. The PCV was determined using microhaematocrit centrifuge. The result of the experiment was analyzed using Analysis of variance (ANOVA). The comparison of mean was separated using a post Hoc test (Least Significant Difference), (William and George, 2008). 


\section{Results}

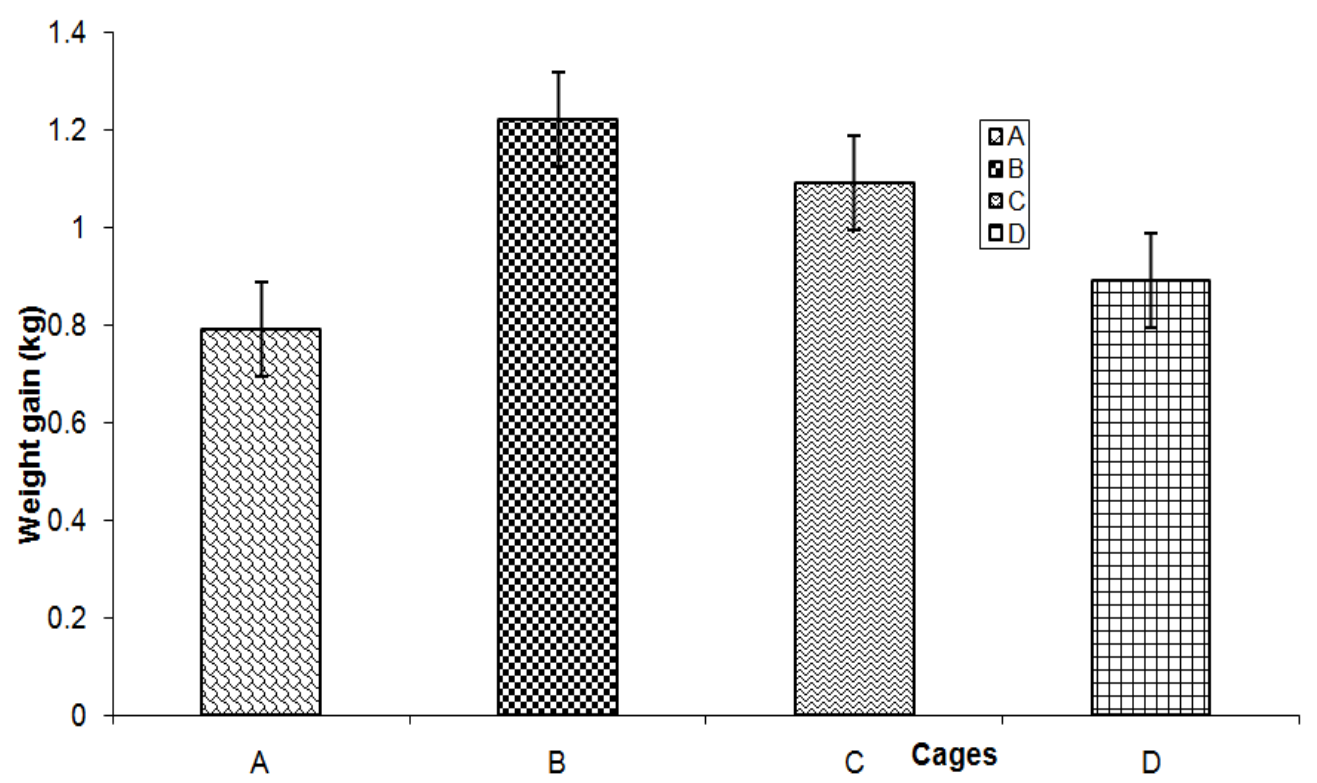

Figure 1. Mean Weight gain of broilers in different treatments.

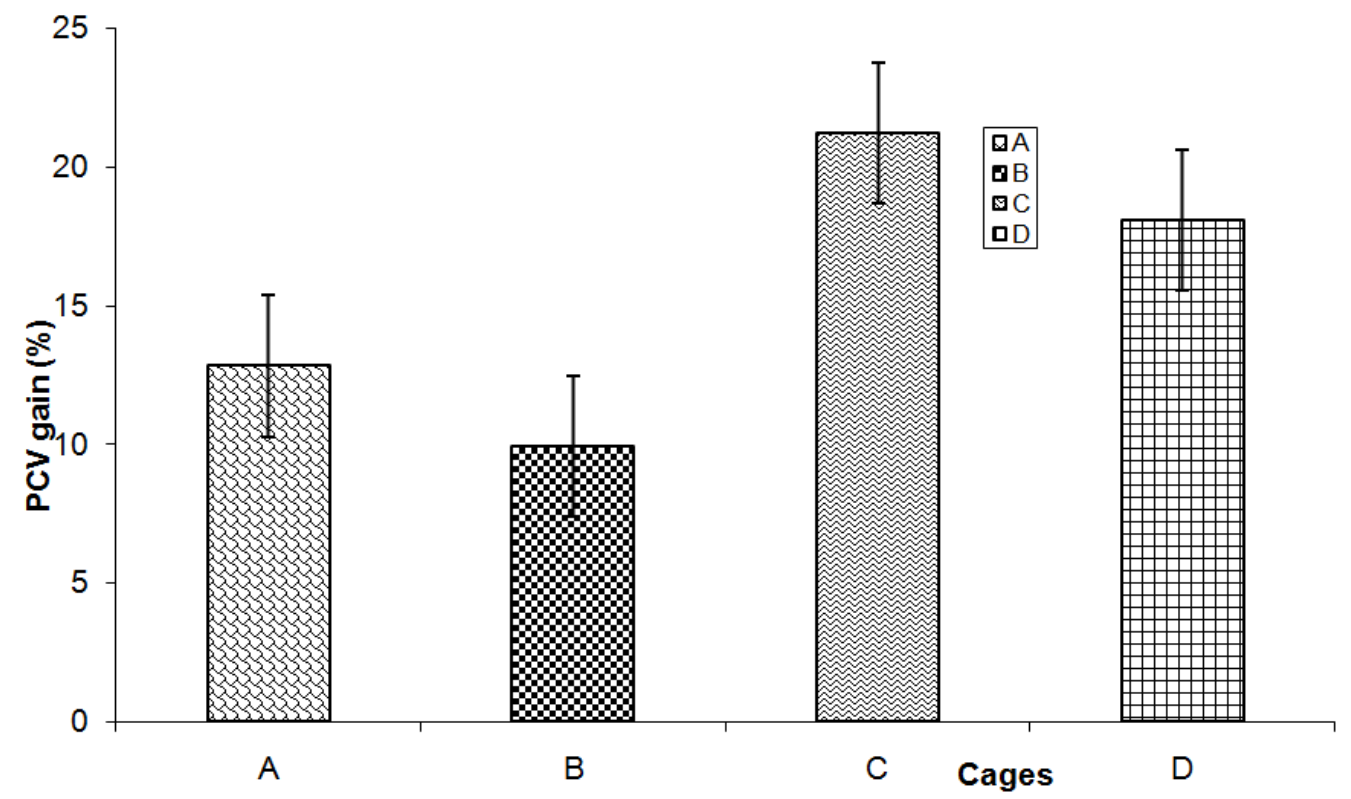

Figure 2. Mean PCV gain of broilers in different treatment.

Figure 1 above indicates that the birds fed with natural ascorbic acid recorded the highest weight gain $(1.22 \mathrm{~kg})$ followed by birds fed with natural and artificial ascorbic acid $(1.09 \mathrm{~kg})$. Broilers fed with artificial ascorbic acid recorded a weight gain of $(0.89 \mathrm{~kg})$ while the control group has the least weight gain of $(0.79 \mathrm{~kg})$. This shows that ascorbic acid has positive influence on the growth performance of broiler chicks, although statistically there was no significant difference, $\mathrm{P}>0.05$.

Figure 2 above shows that the broilers fed with natural and artificial ascorbic acid had the highest PCV gain (21.23), followed by broilers fed with artificial ascorbic acid (18.1).
Broilers on the control diet recorded a PCV gain of (12.84) while broilers fed with natural ascorbic acid recorded the least PCV gain of (9.93). This shows that ascorbic acid enhances the PCV of broiler chicks especially when combine both artificial and natural ones.

\section{Discussion}

The results of the experiment indicated a higher weight gain of broilers fed with natural ascorbic acid $(1.22 \mathrm{~kg})$, followed by broilers fed with natural and artificial ascorbic acid $(1.09 \mathrm{~kg})$. Broilers fed with artificial ascorbic acid 
recorded a weight gain of $(0.89 \mathrm{~kg})$ while the control group has the least weight gain of $(0.79 \mathrm{~kg})$. The result of this study is in agreement with those of Quarles and Adrian (1989) who reported that when vitamin $\mathrm{C}$ was supplemented in the drinking water for 24 hours prior to pick up for slaughter, carcass yield was significantly increased. Result from the study has shown that mixture of natural and artificial ascorbic acid has a significant increase in the PCV of broilers when compared with natural and artificial ascorbic acid individually. Broilers fed with natural and artificial ascorbic acid recorded the highest PCV gain $(21.23 \%)$, this may be attributed to the fact that vitamin $\mathrm{C}$ is part of a matrix involving many beneficial phytochemicals like cyanidin-3glucoside, flavonoides and carotenoids, (Kurl et al., 2002). Also it is vital for the body to receive an optimal amount of vitamin $\mathrm{C}$ because the production of collagen is linked directly to vitamin $\mathrm{C}$; therefore, if there is a lack of vitamin $\mathrm{C}$, there is an absence of collagen, and the body will literally fall. Due to these functions, vitamin $\mathrm{C}$ especially in combination with zinc is also important for the healing of wounds, (Escott-Stump, 2008). Ibiyo et al., (2006) stated that vitamin $\mathrm{C}$ improves immune function and improve growth, this manifested in this research. Furthermore, it is good to note that a rapid growing broiler needs to be supplied with sufficient amount of protein and carbohydrates, along with the necessary vitamins, dietary minerals and an adequate supply of water in order to meet its requirements for maintenance and growth of all components of the bird and because vitamin $\mathrm{C}$ is soluble in water, it makes it easier for the birds to take it in when mixed with water, this will prevent dehydration. If the water changes taste that is not palatable or have suspensions, the birds may not drink it.

\section{Conclusion}

Ascorbic acid enhances the growth performance of broiler chicks and also boosts their PCV. It is therefore recommended that ascorbic acid supplementation will be an inclusion in the feed formation for broiler chicks. This will enhance meat production and as well alleviate problems of protein deficiencies in Nigerian meals.

\section{References}

[1] Adejoro, S. N. (2000). Handbook for Poultry Practioner and Consultants. Ben Press, Ibadan. Sovet Nig Ltd pp-33.

[2] Aletor, V. A. and Osungwu, C. I. (1992): The Effect of Soybeans on the Serum Constituent and Bone of mineralization of chicken. B. Sc Thesis. Department of Animal Production and Health School of Agriculture and Agricultural Technology, Federal University of Technology, Akure, Ondo State, Nigeria.

[3] Apata, D. F. and Ojo, V. (2000). Efficiency of the Trichordema Viride Enzyme complex in Broiler Starter Fed Cowpea Tester
Based Diets. Book of Proceedings of the 25th Annual Conference of Nigerian of Society of Animal Production, pp132-133.

[4] Brooks, M. C. (2001). Effect of Protein on Human Growth and Development. International Journal of Nutrition, (25) 4635 .

[5] Bull B.S., D’Onofrio G, Fujimoto K,(2001). Recommendation for reference method for the packed cell volume (ICSH Standard 2001). Laboratory Hematology, 7:148-170.

[6] Douglas, L. (2003). Innovative Development in the Production and Delivery of Alternative Protein Source. International Journal of Animal Science, 25: 104-150.

[7] Douglas, R. M., Hemila, H., Chalker, E., Treacy, B. (2007). Vitamin $\mathrm{C}$ for preventing and treating the common cold. Cochrane Database System Review; (3):CD000980.

[8] Ene, L. S. O (1987). “ Welcoming Address" In: Jerry, E. R., Akoroda, M. O. and Arene, O. B (ed). Tropical Root Crops: Root Crops and the African Food Crisis Proceedings of the Third Triennial Symposium of the International Society for Tropical Root Crops, p.4.

[9] Escott-Stump, S., (2008). Nutrition and Diagnosis-Related Care. 6th edition. Philadelphia, Pa: Lippincott Williams \& Wilkins.

[10] Gillespie, J. R., Flanders, F. B. (2010). Modern Livestock and Poultry Production. Cengage Learning. p693.

[11] Gross, W.B., P.B. Siegel and R.T. Dubose, (1980). Some effects of feeding corticosterone to chickens. Poultry Science, 59: 516-522.

[12] Ibiyo, L. M. O., Madu, C. T., and Eze, S. S. (2006). Effects of Vitamin C Supplementation on the Growth of Heterobranchus longifilis fingerlings. Animal Nutrition Journal, 60 (4): 325332 .

[13] Kurl, S., Tuomainen, T. P., Laukkanen, J. A. (2002). Plasma vitamin $\mathrm{C}$ modifies the association between hypertension and risk of stroke; American Heart Association Journal, 33(6):1568-73.

[14] Li, Y. and Schellhorn, H. E. (2007). New developments and novel therapeutic perspectives for vitamin C. Journal of Nutrition, 137:2171-84.

[15] Pardue, S.L., Thaxton, J.B. and Brake, (1985). Influence of supplemental ascorbic acid on broiler performance following exposure to high environmental temperature. Poultry Science, 64: 1334-1338.

[16] Quarles, C.L. and Adrian, W.J. (1989). Evaluation of ascorbic acid for increasing carcass yield in broiler chickens. The role of vitamin $\mathrm{C}$ for poultry stress management. F. Hoffmann. Laroche and Co.AG., Switzerland.

[17] Schemling, S.K. and Nockles, C.F. (1978). Effect of age, sex and ascorbic acid ingestion on chicken plasma corticosterone levels. Poultry Science, 57:527-533.

[18] William, A.C., and George, W.S. (2008). Statistical Methods, $6^{\text {th }}$ Ed., The Iowa State University Press. Ames, Iowa, USA. Pp. 167-263. 